\title{
Isbrueckerichthys epakmos, a new species of loricariid catfish from the rio Ribeira de Iguape basin, Brazil (Teleostei: Siluriformes)
}

\author{
Edson H. L. Pereira* and Osvaldo T. Oyakawa**
}

Isbrueckerichthys epakmos, new species, is described from the tributaries of the rio Juquiá, rio Ribeira de Iguape basin, São Paulo State, Brazil. The new species displays a unique sexual dimorphism. Mature males are distinguished from its congeners by having a well-developed soft fleshy area and a clump of hypertrophied short odontodes directed forward or slightly upward on anterior portion of snout. It is compared with I. duseni and I. alipionis, which occurs sympatrically in the rio Ribeira de Iguape drainage. A key to the species of Isbrueckerichthys is provided.

Isbrueckerichthys epakmos, nova espécie, é descrita a partir de exemplares capturados em afluentes do rio Juquiá, bacia do rio Ribeira de Iguape no estado de São Paulo, Brasil. A nova espécie se distingue dos outros congeneres pela presença em machos adultos de uma área intumescida bem desenvolvida e um conjunto de odontódeos hipertrofiados curtos e inclinados para frente ou ligeiramente voltados para cima na porção anterior do focinho. A nova espécie é comparada com I. duseni e $I$. alipionis que ocorrem simpatricamente na bacia do rio Ribeira de Iguape. Uma chave de identificação para as espécies de Isbrueckerichthys é fornecida.

Key words: Atlantic Forest, systematics, Isbrueckerichthys duseni, Isbrueckerichthys alipionis.

\section{Introduction}

The rio Ribeira de Iguape basin is one of the largest coastal river basins in southeastern Brazil, being the Juquiá and São Lourenço rivers its main tributaries. An important ecological aspect is that this river system is totally included inside one of the largest remnants of Atlantic Forest of southeastern Brazil, where on São Paulo State alone there are nine conservation units in the form of parks and ecological stations. Threats to Atlantic Forest ecosystems include the degradation of natural streams and rivers caused by loss of ciliary vegetation, erosion, siltation, organic and chemical pollution, damming, and introductions of exotic species. Fishes are probably the least known vertebrates in the Atlantic Forest, partly due to lack of taxonomic and systematics information (Rosa \& Menezes, 1996).

During ichthyological surveys lead by MCP and inventory field studies related to the MZUSP project "Fish diversity of the streams and headwaters of the rio Ribeira de Iguape in the State of São Paulo", the upper portions of this basin were extensively sampled (Fig. 1). Among the armored catfishes, or Loricariidae, specimens of the genus Isbrueckerichthys Derijst, 1996 were regularly collected in several small tributaries. The genus is composed of medium-sized species of loricariids (cascudos) which are found in small to medium headwater streams with clear, fast-running, and welloxygenated water, where the bottom is composed of boulders, rocks, and sometimes gravel.

The genus Isbrueckerichthys was proposed by Derijst (1996) who transferred Pareiorhaphis duseni (Miranda Ribeiro, 1907) and P. alipionis Gosline, 1947 to the new genus. This proposal was justified based on the discovery of an earlier type-species designation by Regan (1920), which had fixed Hemipsilichthys calmoni Steindachner, 1907 as the type species of genus Pareiorhaphis, making Pareiorhaphis a synonym of the Hemipsilichthys (see comments in Pereira \& Reis, 2002:141). Two species of Isbrueckerichthys were previously recognized in the rio Ribeira de Iguape drainage.

\footnotetext{
* Museu de Ciências e Tecnologia, PUCRS, P. O. Box 1429, 90619-900 Porto Alegre, RS, Brazil. e-mail: edsonhlp@pucrs.br ** Museu de Zoologia da Universidade de São Paulo, P. O. Box 42594, 04299-970 São Paulo, SP, Brazil. e-mail: oyakawa@usp.br
} 
Isbrueckerichthys duseni from the upper reaches of that basin in Paraná State and I. alipionis, from the rio Betari, rio Iporanga basin. The comparative study of numerous specimens collected in this basin revealed the presence of another undescribed species, I. epakmos sp. n. from a tributary of the rio Juquiá in the São Paulo State. In this paper we describe the new species, diagnose it from its congeners, and compare it to other related genera.

\section{Material and Methods}

Specimens examined belong to the Museu de Ciências e Tecnologia, Pontifícia Universidade Católica do Rio Grande do Sul, Porto Alegre (MCP) and Museu de Zoologia da Universidade de São Paulo, São Paulo, (MZUSP). Measurements and counts of bilaterally symmetrical features were taken from the left side of the body when possible; if a feature was missing or broken on the left side, it was examined on the right side. Body plate counts and nomenclature follow Schaefer (1997). Measurements follow Weber (1985). Additional measurements and counts include: (1) postdorsal length, measured from end of dorsal-fin base to posterior hypural margin; (2) anal-fin spine length, measured from its origin to its distal tip; (3) body depth at dorsal-fin origin; (4) body width at dorsal-fin origin; (5) body width at analfin origin; (6) caudal peduncle length, measured from origin of anal fin to posterior hypural margin; (7) caudal peduncle width, taken at point of least depth; (8) length of mandibular ramus, measured by pressing the calipers on the long axis of the dentary bone (presented as the average of left and right dentaries in Table 1); (9) plates lateral to dorsal-fin base (number of plates in dorsal series along the dorsal-fin base); (10) plates between dorsal and adipose fins (number of plates in dorsal series between last dorsal-fin branched ray insertion and origin of adipose-fin spine); (11) plates between adipose and caudal fins (number of plates in dorsal series between the adipose membrane and posterior hypural margin); (12) plates lateral to anal-fin base (number of plates in ventral series along the anal-fin base); (13) plates between anal and caudal fins (number of plates in ventral series between the last anal-fin branched ray insertion and posterior hypural margin); (14) azygous plates (number of azygous plates preceding the adipose-fin spine); (15) premaxillary and dentary teeth (counted separately in both sides). In case of missing teeth, the space left was counted as a tooth.

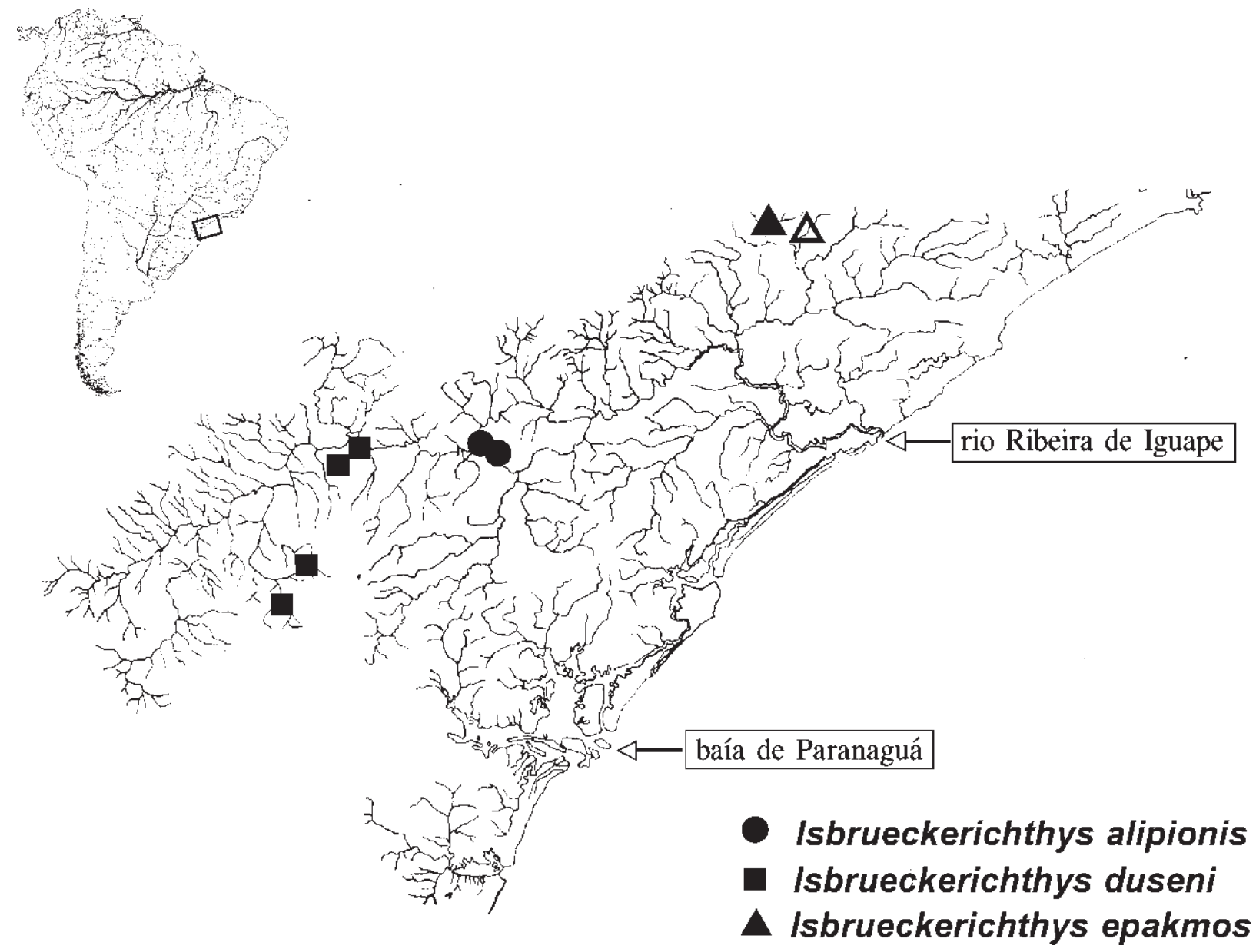

Fig. 1. Geographic distribution of Isbrueckerichthys species in southeastern coastal Brazil. Open symbol represents type-locality. 


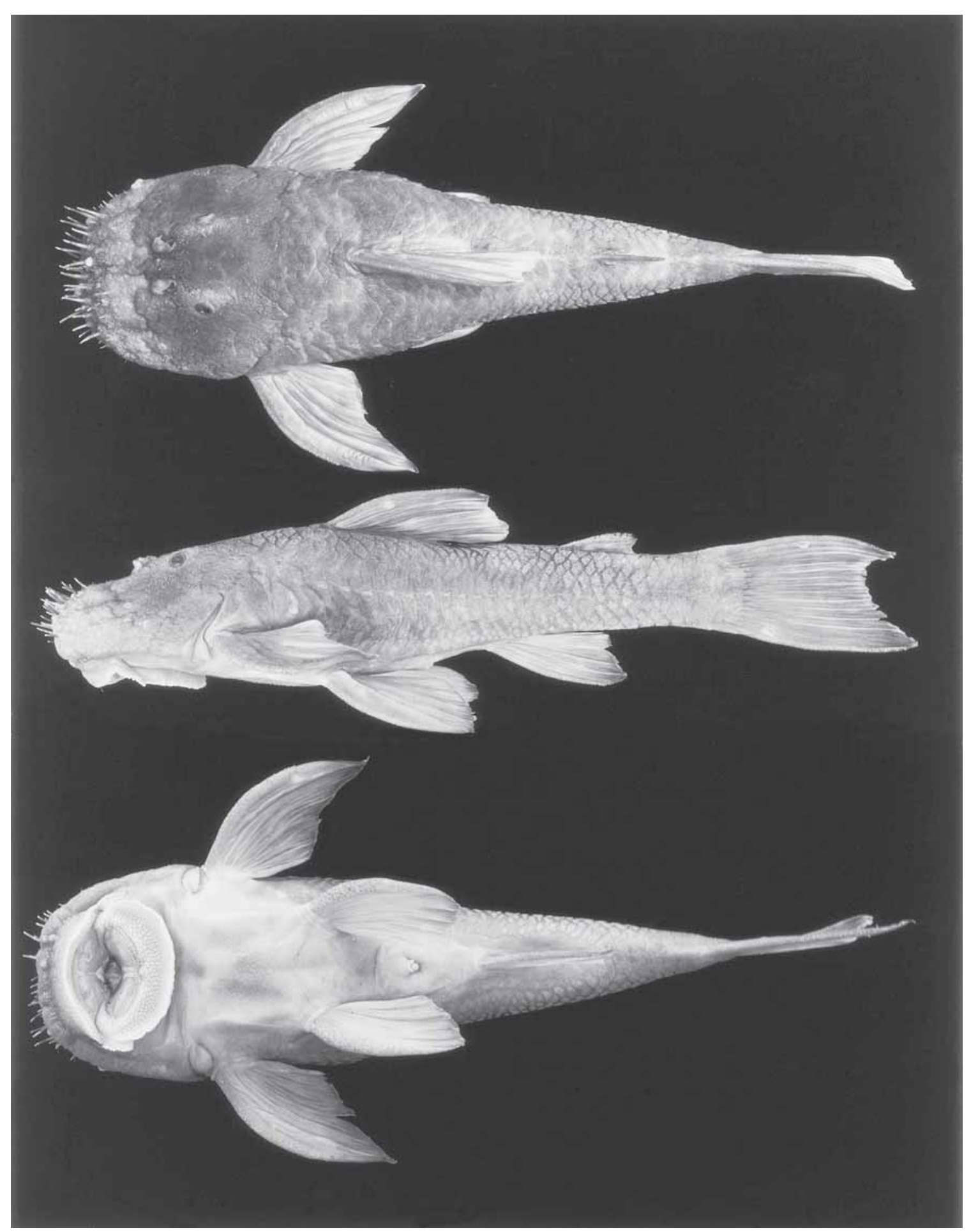

Fig. 2. Isbrueckerichthys epakmos, holotype, MZUSP 79804, male, 103.1 mm SL. Brazil: São Paulo: Tapiraí, rio Verde.

All measurements were taken point to point with digital calipers to the nearest $0.1 \mathrm{~mm}$. Standard length is expressed in $\mathrm{mm}$. All other measurements are expressed as percents of standard length, except subunits of the head, which are expressed as percents of head length. In the lists of type material museum acronym and catalog number come first, followed by the number of specimens in that lot, the number of specimens measured for the morphometric comparisons in parentheses, the range of standard length, locality, date of collection, and collectors. In the diagnosis for the new species we present distinguishing characters that help to distinguish that species from others. Abbreviations used are SL (standard length) and HL (head length). 


\section{Results \\ Isbrueckerichthys epakmos, new species}

Fig. 2

Holotype. MZUSP 79804, male, 103.1 mm SL; Brazil: São Paulo: Tapiraí: rio Ribeira de Iguape drainage, rio Verde at Piúva, on road to Rio Verde, 2358'22"S 47³4'23"W, 27 Jun 2002, O. T. Oyakawa, F. C. T. Lima, J. C. Nolasco \& V. Moreira.

Paratypes. Brazil: São Paulo: MZUSP 79498, 4 (1) 33.2-66.7 mm SL; collected with the holotype. MZUSP 78444, 6 (4) 28.1$78.2 \mathrm{~mm}$ SL; Ibiúna: creek tributary of rio Juquiá at Cachoeira da Fumaça, 24²'18"S 47¹4'53"W, 20 Oct 2001, A. Akama, J. C. Nolasco, O. T. Oyakawa, M. Ghazzi \& R. T. Nakasumi. MCP 28276, 63 (20) 39.5-83.3 mm SL; Tapiraí: rio Coruja, tributary to rio Juquiá, on road from Tapiraí to Juquiá near Cachoeira do Chá, 241'47'S 47³4'29'W, 29 Jan 2001, C. A. S Lucena, J. F. P. da Silva, E. H. L. Pereira \& A. R. Cardoso.

Diagnosis. Two putative autapomorphies were found for Isbrueckerichthys epakmos. The new species can be distinguished from its congeners by having a soft and rugose fleshy area well developed on anterior portion of snout of mature males (versus mature males with thin soft fleshy area on lateral margins of head or absent); and by the presence of a clump of hypertrophied odontodes located only on anterior portion of snout usually short and thick, directed forward or slightly upward (versus hypertrophied odontodes in mature males situated along lateral margin of head or absent).

Description. Standard length of measured specimens 56.4 to $103.2 \mathrm{~mm}$. Counts and proportional measurements presented in Table 1. Dorsal surface of body covered by plates except for naked area around dorsal fin. Body moderately depressed. Progressively narrowing from cleithrum to end of caudal peduncle. Dorsal profile of body slightly convex, rising from snout tip to origin of dorsal fin and then descending to end of caudal peduncle. Trunk and caudal peduncle mostly ovoid in cross-section, slightly flattened ventrally and more compressed caudally. Greatest body depth at dorsal-fin origin. Ventral surface of head, region from pelvic-fin insertion to anal fin origin and around the anal-fin totally naked. Abdomen covered by minute platelets, scattered between posterior margin of lower lip and insertion of pelvic fin; sometimes concentrated in central area of abdomen.

Head broad and moderately square; without crests. Lateral margin covered with minute hypertrophied odontodes. Snout in lateral profile sloping abruptly towards its tip and slightly straight anteriorly. Mature males with well developed soft fleshy area on anterior portion of snout. Snout slightly concave anteriorly to nostrils. Soft fleshy area ornamented with short and thick hypertrophied odontodes (Figs. 2-3). Females with soft fleshy area but hypertrophied odontodes very short. Eye moderately small (10.6 to $13.5 \%$ of head length), dorsolaterally placed. Iris with minute dorsal flap covering pupil, sometimes absent. Lips roundish and well developed, occupying most of ventral surface of head. Lower lip almost reaching pectoral girdle and covered with minute papillae, which decrease in size towards its edge. Papillate surface of lower lip projecting between dentary and premaxillary rami. Maxillary barbell long, coalesced with lower lip and ornamented with small papillae. Teeth small and bicuspid, inner cusp slightly curved inwards. Lateral cusp small, usually not reaching half-length of inner cusp.

Dorsal fin originating on vertical line passing through pelvic-fin origin; nuchal plate present but spinelet absent and locking mechanism non-functional. Dorsal-fin spine moderately flexible, followed by 7 branched rays. Adipose fin present, preceded by 0-1 median, unpaired pre-adipose azygous plates. Pectoral fin moderate in size; with long, curved spine, covered with short hypertrophied odontodes on lateral margin; dorsal surface with discrete dermal flap along its entire length; 6 branched rays. First branched ray as long as spine. Subsequent branched rays reducing gradually in size. Last ray about half-length of first one. Posterior margin of pectoral fin straight; overlapping approximately half-length of pelvic fin when adpressed in mature males. Pelvic-fin moderate in size, with one spine and 5 branched rays, not reaching insertion of anal fin when adpressed. Pelvic-fin spine depressed, covered with minute odontodes ventrally and laterally; dermal flap on its dorsal surface, very large and extending to tip of spine in mature males. Anal fin with one unbranched and 5 branched rays. Caudal fin border concave; lower lobe slightly longer than upper, 14 branched rays.

Color in alcohol. Dorsal surface of body and head grayish or dark-brown, pale yellow ventrally. Dorsum covered by lighter brown blotches. Usually these blotches forming four saddles on dorsum: on origin of dorsal fin; on posterior portion of dorsal-fin base; between end of dorsal fin and adipose fin, and between adipose and caudal fins. Ventral margin of head, outer portion of upper lip, and ventral portion of caudal peduncle dusky. Spines of dorsal, pectoral, pelvic and anal fins grayish or with 3-4 wide dark stripes. Branched rays homogeneously grayish or with small, dark-brown blotches along entire length, sometimes forming 3 or 4 narrow bands. Caudal fin with 2-3 narrow bands, more visible when fin widely open. Fin membranes hyaline. Ventral surface unpigmented between anal-fin origin and head.

Distribution. Isbrueckerichthys epakmos inhabits in the headwaters of the rio Juquiá, rio Ribeira de Iguape basin in São Paulo State, Brazil (Fig. 1).

Etymology. The species name is from the Greek adjective (= epakmos) meaning in the bloom of age, alluding to the highly developed odontodes on the snout tip in mature males. Gender masculine.

Ecological notes. The rio Verde, a small stream with clear water 
and moderate to strong current, with loose stones and, in some places, sand on the bottom, is located inside the largest remnant of the Atlantic Forest of southeastern Brazil at $700 \mathrm{~m}$ above sea level. It is about $5.0 \mathrm{~m}$ wide and $0.3-0.5 \mathrm{~m}$ depth. The following species occur syntopically with Isbrueckerichthys epakmos: Characidium sp., Rhamdia cf. quelen, Neoplecostomus ribeirensis, 'Cichlasoma' cf. facetum, Geophagus brasiliensis, Phalloceros caudimaculatus.

\section{Key to the species of Isbrueckerichthys}

1 Teeth of dentary and premaxilla with small lateral cusp; pectoral-fin spine short (16.4-21.4\% SL) 2

1' Teeth of dentary and premaxilla simple, without lateral cusp; pectoral-fin spine long (27.4-32.0\% SL). I. alipionis

2 Mature males with large and rugose soft fleshy area on anterior portion of snout; more developed, hypertrophied odontodes inserted on anterior portion of snout (odontodes directed upward; short and usually strong) ........ I. epakmos

2' Mature males with thin soft fleshy area on lateral margins of head; more developed, hypertrophied odontodes inserted on cheeks (odontodes directed outward and usually weak) ......

I. duseni

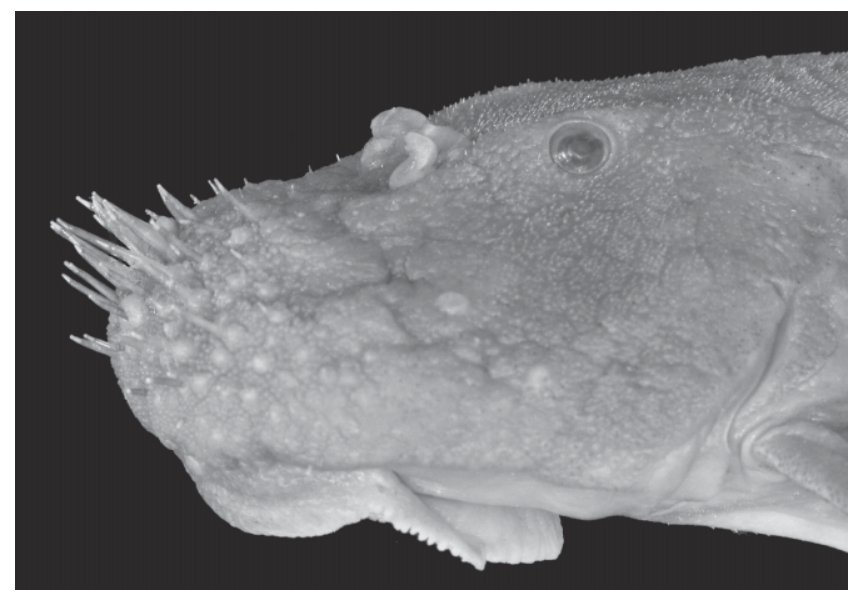

Fig. 3. Isbrueckerichthys epakmos, holotype, MZUSP 79804, detail of head, showing its well-developed odontodes and soft fleshy lobe.

\section{Discussion}

Isbrueckerichthys is a genus of the loricariid subfamily Hypostominae (sensu Isbruicker, 1980), or of the subfamily Neoplecostominae (sensu Gosline, 1947). A phylogenetic diagnosis for the genus Isbrueckerichthys is still lacking but species can be distinguished from all other loricariids by the combination of the following characters: small to medium size, small naked area behind the pterotic-supracleithrum, abdomen with small platelets imbedded in skin between pectoral girdle and pelvic-fin insertions, dorsal fin with one spine and, seven branched rays and caudal peduncle ovoid in cross-section.

Montoya-Burgos et al. (1998) suggested that Pareiorhina Gosline, 1947, Kronichthys Miranda Ribeiro, 1908, Hemipsilichthys splendens Bizerril, 1995, Hemipsilichthys sp., Neoplecostomus Eigenmann \& Eigenmann, 1888, and Isbrueckerichthys duseni, form a clade within the loricariids, corroborating the proposition of Gosline (1947) of a more encompassing subfamily Neoplecostominae. The genus Isbrueckerichthys is distinguished from all these genera except Neoplecostomus by having the abdomen covered with small platelets between pectoral girdle and pelvicfin insertions. From Neoplecostomus it is easily distinguished by lacking a series of papillae on lower lip after of the dentaries. The most distinctive features of I. epakmos are the anterior portion of head ornamented with a large and rugose soft fleshy area and the presence of a clump of hypertrophied odontodes located only on anterior portion of snout, usually short and thick, directed forward or slightly upward on adult males. The condition present in I. epakmos differs from that of I. duseni which has a thin soft fleshy area on lateral margins of head, more developed hypertrophied odontodes inserted on cheeks and directed outward on adult males. The two features observed in I. epakmos are absent on I. alipionis. Among the Loricariidae Neblinichthys pilosus Ferraris et al., 1986 is phenetically similar to I. epakmos, but it can be easily distinguished by the possession of eversible odontodes on interopercle.

Several genera of Loricariidae are widely distributed in southeastern coastal basins in Brazil, including the rio Ribeira de Iguape basin: Kronichthys, Neoplecostomus, Harttia Steindachner, 1876, Rineloricaria Bleeker, 1862, Ancistrus Kner, 1854, Parotocinclus Eigenmann \& Eigenmann, 1889, and Hypostomus La Cepède, 1803. Contrary to these genera the three species of Isbrueckerichthys are found only in the headwaters of the rio Ribeira de Iguape basin, the genus being endemic to that drainage. Isbrueckerichthys epakmos and its congeners showing a restrict distribution provide additional evidence for the recognition of the rio Ribeira de Iguape drainage as an area of endemism in South America. The phylogenetic significance of the characters discussed here is not yet understood. The complete understanding of Isbrueckerichthys awaits a thorough phylogenetic study of the genera Pareiorhaphis, Hemipsilichthys, Pareiorhina, Kronichthys and Neoplecostomus (in progress by the senior author). Despite the fact that Isbrueckerichthys has not yet been phylogenetically defined, we have tentatively chosen to assign the new species to this genus.

Comparative material. Isbrueckerichthys duseni: Brazil: Paraná State: rio Ribeira de Iguape basin: MCP 20128, 14, 23.5-95.2 mm SL; rio Piedade on road from Rio Branco do Sul to Açungui, ca. 26 km WNW of Rio Branco do Sul. - MCP 12557, 20 (7), 28.6$98.8 \mathrm{~mm}$ SL; ribeirão Pulador, $3 \mathrm{~km}$ S of Campinhos on highway BR 476, Cerro Azul. - MCP 12564, 28 (7), 23.8-91.1 mm SL; ribeirão Pocinha, $4 \mathrm{~km} \mathrm{~S}$ of Tunas on highway BR 476, Bocaiuva 
do Sul. -Isbrueckerichthys alipionis: Brazil: São Paulo State: rio Ribeira de Iguape basin: MCP 19607, 21 (5), 70.0-81.5 mm SL; rio Betari at Parque Estadual Turístico do Alto Ribeira, Iporanga. - MCP 20122, 6, 38.7-80.7 mm SL; Córrego Areias, ca $1 \mathrm{~km}$ SE from Bairro da Serra, on road from Apiaí to Iporanga. - MZUSP 58550, 33 (4), 74.9-80.2 mm SL; rio Betari near the Parque Estadual Turístico do Alto Ribeira, Iporanga. - MCP 26952, 24, 29.2-86.8 mm SL; rio Betari, Iporanga. Neoplecostomus microps: Brazil: São Paulo State: rio Paraíba do Sul basin: MCP 20069, 4, 47.1-89.3 mm SL; Ribeirão Benfica at Benfica, ca $1 \mathrm{~km}$ from Piquete. - MCP 20071, 13, 45.1-98.3 mm SL; Ribeirão Macacos at Bairro dos Macacos, tributary of rio Paraitinga, Silveiras. Hemipsilichthys stephanus: Brazil: Minas Gerais State: MZUSP 36971, holotype, $97.1 \mathrm{~mm}$ SL; Ribeirão das Pedras, tributary of rio Jequitinhonha, ca $1300 \mathrm{~m}$ a.s.1., $3 \mathrm{~km}$ N of Diamantina. Neblinichthys pilosus: Venezuela: Territorio Federal Amazonas: Dept. Río Negro: río Baria basin: MZUSP 35217, Paratypes, 2, 48.0-50.6 mm SL, río Mawarinuma tributary, at Neblina base camp, on right bank in riffle.

Table 1. Descriptive morphometric and meristic of Isbrueckerichthys species. Values are given as ranges for all measured specimens. Standard length is expressed in $\mathrm{mm}$.

\begin{tabular}{|c|c|c|c|c|}
\hline \multirow[b]{2}{*}{ Character } & \multicolumn{2}{|c|}{ I. epakmos } & \multirow{2}{*}{$\begin{array}{l}\text { I. duseni } \\
\mathrm{n}=16\end{array}$} & \multirow{2}{*}{$\begin{array}{l}\text { I. alipionis } \\
\mathrm{n}=14\end{array}$} \\
\hline & Holotype & $n=25$ & & \\
\hline Standard length (mm) & 103.2 & $56.4-86.5$ & $47.0-98.8$ & $52.4-81.5$ \\
\hline \multicolumn{5}{|l|}{ Percents of standard length } \\
\hline Head length & 32.8 & $31.8-36.5$ & $31.3-35.3$ & $28.8-34.2$ \\
\hline Predorsal length & 42.6 & $42.0-48.0$ & 40.4-44.1 & $40.0-45.2$ \\
\hline Postdorsal length & 42.6 & $37.7-43.6$ & $41.7-44.1$ & $41.6-46.8$ \\
\hline Dorsal-fin spine length & 24.7 & $19.3-24.1$ & $21.7-23.8$ & $22.2-25.4$ \\
\hline Anal-fin spine length & 19.8 & $15.4-19.3$ & $15.9-19.5$ & $15.8-19.6$ \\
\hline Pectoral-fin spine length & 19.7 & $16.4-21.3$ & $17.3-21.4$ & $27.4-32.0$ \\
\hline Pelvic-fin spine length & 22.2 & $18.8-22.2$ & $17.3-22.0$ & $20.3-24.2$ \\
\hline Upper caudal-fin ray & 25.1 & $21.6-27.1$ & $20.2-25.5$ & $21.4-24.0$ \\
\hline Lower caudal-fin ray & 28.4 & $23.9-28.4$ & $22.0-28.0$ & $24.4-26.9$ \\
\hline Trunk length & 17.3 & $14.6-19.4$ & $15.3-18.3$ & $14.5-18.0$ \\
\hline Abdominal length & 24.1 & $21.3-26.6$ & $22.5-25.5$ & $24.1-26.5$ \\
\hline Cleithral width & 30.3 & 27.6-30.9 & 27.9-32.9 & $27.6-30.7$ \\
\hline Body depth at dorsal origin & 24.1 & $19.2-25.5$ & $16.7-21.6$ & $18.1-22.1$ \\
\hline Body width at dorsal origin & 26.2 & $17.9-27.0$ & $24.0-24.5$ & $19.0-24.1$ \\
\hline Body width at anal origin & 15.5 & $9.1-15.5$ & $11.5-15.5$ & $11.8-18.1$ \\
\hline Caudal peduncle length & 36.4 & $31.2-39.3$ & $34.6-38.2$ & $37.0-39.2$ \\
\hline Caudal peduncle depth & 10.5 & 7.6-10.3 & $8.3-10.4$ & $9.1-11.4$ \\
\hline Caudal peduncle width & 6.1 & $3.9-6.0$ & 4.3-6.4 & $4.3-6.5$ \\
\hline \multicolumn{5}{|l|}{ Percents of head length } \\
\hline Snout length & 63.7 & $60.2-67.1$ & $56.6-64.9$ & $63.1-66.7$ \\
\hline Orbital diameter & 10.6 & $10.6-13.5$ & $11.3-13.9$ & $11.0-13.9$ \\
\hline Least interorbital width & 30.0 & 29.1-34.4 & 29.9-33.6 & $26.4-30.7$ \\
\hline Head depth & 63.7 & $51.0-65.5$ & $50.7-63.6$ & $52.4-67.5$ \\
\hline Mandibular ramus & 21.5 & $19.8-25.0$ & $19.4-22.7$ & $22.9-25.7$ \\
\hline \multicolumn{5}{|l|}{ Counts } \\
\hline Lateral plates & 30 & $27-33$ & $27-34$ & $28-33$ \\
\hline Premaxillary teeth & 34 & $30-52$ & $29-47$ & $34-50$ \\
\hline Dentary teeth & 34 & $30-53$ & $28-46$ & $35-47$ \\
\hline Plates lateral to dorsal fin & 8 & $6-10$ & $5-8$ & $7-11$ \\
\hline Plates between dorsal / adipose & 10 & $7-10$ & $6-9$ & $9-12$ \\
\hline Plates between adipose / caudal & 5 & $4-8$ & 4-6 & $4-6$ \\
\hline Plates lateral to anal fin & 7 & $3-7$ & 4-6 & $3-4$ \\
\hline Plates between anal / caudal & 16 & $10-15$ & $12-15$ & $12-14$ \\
\hline
\end{tabular}




\section{Acknowledgments}

We are grateful to the colleagues Roberto E. Reis (MCP), Paulo H. F. Lucinda (UNITINS) and Jonathan W. Armbruster (AUM) for their comments and suggestions on the manuscript. Carlos A. S. Lucena, Alexandre R. Cardoso, José F. P. da Silva, Flavio C. T. Lima, José C. Nolasco and Vivian M. de Oliveira for important help in collecting of specimens. Jeter J. Bertoletti, director of MCP, for his continued friendship and support to EHLP. Portions of the research associated with this paper were financed by FINEP/CNPq PRONEX Project No. 661058 / 1997-2 and BIOTA/FAPESP (no. 00/04300-9).

\section{Literature Cited}

Derijst, E. 1996. Note on the type species of the mailed catfish genus Hemipsilichthys Miranda Ribeiro, 1918 (Pisces: Siluriformes: Loricariidae), with the introduction of Isbrueckerichthys nom. nov. Aquarium Wereld, 49: 62-64.

Gosline, W. A. 1947. Contributions to the classification of the loricariid catfishes. Arquivos do Museu Nacional, 41: 79134.

Isbrücker, I. J. H. 1980. Classification and catalogue of the mailed Loricariidae (Pisces, Siluriformes). Verslagen en Technische Gegevens, Instituut voor Taxonomische Zoölogie, Universiteit van Amsterdam, 22: 1-181.

Miranda Ribeiro, A. 1907. Peixes do Iporanga - S. Paulo Resultados de excursões do Sr. Ricardo Krone, membro correspondente do Museu Nacional do Rio de Janeiro. A lavoura, 11: 185-190.
Montoya-Burgos, J. I., S. Muller, C. Weber \& J. Pawlowski. 1998. Phylogenetic relationships of the loricariidae (Siluriformes) based on mitochondrial rRNA gene sequences. Pp. 363-374. In: L. R. Malabarba, R. E. Reis, R. P. Vari, Z. M S. Lucena \& C. A. S. Lucena (Eds.). Phylogeny and Classification of Neotropical Fishes. Porto Alegre, Edipucrs, 603p.

Pereira, E. H. L. \& R. E. Reis. 2002. Revision of the loricariid genera Hemipsilichthys and Isbrueckerichthys (Teleostei: Siluriformes), with description of five new species of Hemipsilichthys. Ichthyological Exploration of Freshwaters, 13: 97-146.

Regan, C. T. 1920. XV - Pisces. Zoological Record [1918], 55: $1-19$.

Rosa, R. S. \& N. A. Menezes. 1996. Relação preliminar das espécies de peixes (Pisces, Elasmobranchii, Actinopterygii) ameaçadas no Brasil. Revista Brasileira de Zoologia, 13 (3): 647-667.

Schaefer, S. A. 1997. The neotropical cascudinhos: systematics and biogeography of the Otocinclus catfishes (Siluriformes: Loricariidae). Proceedings of the Academy of Natural Sciences of Philadelphia, 148: 1-120.

Weber, C. 1985. Hypostomus dlouhyi, nouvelle espèce de poisson-chat cuirassé du Paraguay (Pisces, Siluriformes, Loricariidae). Revue Suisse de Zoologie, 92 (4): 955-968.

Received February 5, 2003 Accepted July 8, 2003 